\title{
Synergistic effects of parabens and plastic nanoparticles on proliferation of human breast cancer cells
}

\author{
Željka Roje ${ }^{1 *}$, Krunoslav Ilić2*, Emerik Galić ${ }^{2}$ Ivan Pavičić ${ }^{2}$, Petra Turčić3 ${ }^{3}$ Zdenko Stanec ${ }^{4}$, and \\ Ivana Vinković Vrček ${ }^{2}$ \\ ${ }^{1}$ Department for Plastic, Reconstructive and Aesthetic Surgery, University Hospital Dubrava, Zagreb, Croatia \\ ${ }^{2}$ Institute for Medical Research and Occupational Health, Zagreb, Croatia \\ ${ }^{3}$ Faculty of Pharmacy and Biochemistry, University of Zagreb, Zagreb, Croatia \\ ${ }^{4}$ School of Medicine, University of Zagreb, Zagreb, Croatia
}

[Received in November 2019; Similarity Check in November 2019; Accepted in December 2019]

\begin{abstract}
Many personal care products on the market contain endocrine disrupting chemicals, including parabens. Parabens are well known chemical additives used as preservatives. They have been found in mammary glands and breast cancer tissues. At the same time, the general public is increasingly exposed to plastic micro- and nanoparticles generated during plastic production and waste disposal. Exposure to chemical cocktails is a realistic scenario of high public health interest, in which many types of compounds such as these two may exhibit synergistic or additive adverse effects. This study evaluated the effects of plastic nanoparticles, parabens, and their mixture on the viability and proliferation of two human breast cancer cell lines: MDA-MB 231, which lacks oestrogen receptors, and MCF-7, which expresses these receptors. Parabens increased proliferation of oestrogen-sensitive breast cancer cells, and this effect became synergistic in the presence of plastic nanoparticles. The mechanism behind synergy may be related to the translocation and adsorption properties of nanoplastics, which served as a Trojan horse to expose cells to parabens more efficiently. These preliminary findings support growing evidence warning about the urgent problem of human exposure to combinations of plastic waste and contingent chemicals.
\end{abstract}

KEY WORDS: endocrine disrupting chemicals; chemical cocktails; MCF-7; MDA-MB 231; risk assessment; viability

Even though European Chemical Agency's regulation REACH (1) has done a lot to improve the protection of human health and the environment from the risks posed by chemicals, about $30 \%$ still does not comply to this regulation. Among them, of particular concern are endocrine disrupting chemicals (EDCs), defined by the World Health Organization (WHO) as "exogenous substances or mixtures that influence the endocrine system and cause adverse health effects in an intact organism, or its progeny, or (sub) populations" (3). Little is still known about the presence of EDCs in consumer products and exposure levels for the general population. To address this issue, the European Commission has recently published a communication on EDCs, announcing intention to establish a horizontal approach to identifying EDCs across all relevant EU legislation (4). At the same time, Health and Environment Alliance calls for an urgent EU action plan to save billions of euros in health-related costs on yearly basis (5). Until well-defined and clear action plan on EDCs is delivered, the only relevant tool to be employed for regulating EDCs is the precautionary principle, which should be based on

Corresponding author: Ivana Vinković Vrček, Institute for Medical Research and Occupational Health, Ksaverska cesta 2, 10000 Zagreb, E-mail: ivinkovic@imi.hr

*These two authors have contributed to this paper equally and share first authorship. early warnings, as highlighted by the European Environment Agency (6).

The most known and studied EDCs are phthalates, parabens, and bisphenol $\mathrm{A}$, present in a wide range of products used by the general population, such as food, drinks, pharmaceuticals, personal care products, or packaging materials. Oestrogenic activity of parabens was first reported almost 20 years ago (7). Since then, a vast number of research has evidenced different modes of paraben action, including their ability to reach blood and different tissues, their binding affinity to oestrogen receptors, their potential to trigger the growth of oestrogenresponsive breast cancer, or their impact on male reproductive function (8-11). Considering that most personal care products on the market contain parabens as preservatives, and that parabens have been found in mammary glands and breast cancer tissues (12), there is continuous interest to elucidate adverse outcome pathways of parabens or chemical mixtures containing them in humans (13).

Particular interest has been focused on realistic scenarios of exposure to chemical cocktails in which many types of EDCs act together with other types of chemicals (9). One such scenario is exposure to plastic debris that originates from plastic waste. This is an alarming environmental and health issue in itself, but also from the 
hormone-disrupting point of view, as most plastics release EDCs (14). Enormous global production and use of plastics has been responsible for the pollution of environment with tens of millions of tonnes of plastic waste that gradually degrades into micro- and nanoparticles (15). Recent reports estimate that trillions of plastic particles lie on the surface of the oceans (16). Humans are exposed to these plastic micro- or nanoparticles through different routes such as food, drinking water, or personal care products of cosmetic industry, which contain plastic particles by design (17). The aim of this study, preliminary in its character, was therefore to evaluate the effects of parabens and plastic nanoparticles, separately and in combination, on the viability and proliferation of two cell lines derived from human breast adenocarcinoma: the highly aggressive and poorly differentiated MDA-MB 231, which lacks HER2, progesterone, and oestrogen receptors, and MCF-7, a more differentiated cell line, morphologically similar to mammary epithelium, which expresses progesterone receptor and oestrogen receptor alpha $(\mathrm{ER} \alpha)$. The cells were treated with polystyrene nanoparticles (PSNP) or a mixture of methyl-, ethyl, propyl- and butylparaben (PBmix), or a cocktail of PSNP and PBmix. The choice of both was based on the plethora of already published findings of their separate action in vitro. With our preliminary data we hoped to complement the existing early warnings about the urgent issue of increasing human exposure to plastic waste and contingent chemicals.

\section{MATERIALS AND METHODS}

\section{Reagents}

Dulbecco's Modified Eagle's Medium (DMEM), phosphate-buffered saline (PBS), bovine serum albumin (BSA), Triton X-100, ethanol, methylparaben, ethylparaben, $n$-propylparaben, and $n$-butylparaben were obtained from Sigma Chemical Co. (Darmstadt, Germany). Foetal bovine serum (FBS, heat inactivated), penicillin, streptomycin, and trypsin-EDTA were obtained from PAA Laboratories $\mathrm{GmbH}$ (Colbe, Germany). Stock solution of the paraben mixture was prepared by dissolving each paraben in absolute ethanol at the final concentration of $100 \mu \mathrm{g} / \mathrm{mL}$. The final concentration of ethanol in the medium for each paraben was not above $0.2 \%$. At this concentration, ethanol has no effect on cell viability and proliferation. Plastic nanoparticles (PSNP) were purchased from ThermoFisher Scientific (Waltham, MA, USA) as $60 \mathrm{~nm}$ polystyrene nanosphere size standards

CellTiter $96^{\circledR}$ AQueous One Solution Cell Proliferation Assay (MTS) from Promega (Madison, WI, USA) was used for colorimetric determination of the number of viable cells after treatment with PSNP and PBmix. Cell proliferation was quantified with a Muse ${ }^{\circledR}$ Ki67 Proliferation Kit (Luminex Corporation, Madison, WI, USA).

\section{Cell cultures}

MDA-MB 231 and MCF-7 cell lines (ATCC, City of Manassas, VA, USA) were cultured in T75 culture flasks (Eppendorf, Hamburg, Germany) in DMEM supplemented with $10 \% \mathrm{BSA}$ and $1 \%$ of penicillin/streptomycin until they reached $80 \%$ confluence. Cell culture medium was then removed and cells rinsed with sterile PBS, after which they were detached by adding $0.25 \%$ trypsin-EDTA solution and incubated at $37{ }^{\circ} \mathrm{C}$ and $5 \% \mathrm{CO}_{2}$ for $5 \mathrm{~min}$. Detached cells were collected and counted on a TC20 automated cell counter (BioRad, Hercules, CA, USA) and then plated in clear 96-well plates (Eppendorf, Hamburg, Germany) at a density of 10,000 cells per well for the cell viability assay or in clear 6-well plates at a density of 50,000 cells per well for the cell proliferation assay. Plates were then incubated at $37^{\circ} \mathrm{C}$ and $5 \% \mathrm{CO}_{2}$ for $24 \mathrm{~h}$ to allow cell attachment. The following day, culture medium was removed from the wells and replaced with a fresh one. Cells were then treated with PBmix, PSNP, or the PBmix + PSNP cocktail. The final tested concentrations in the wells were 1,10 , and $100 \mu \mathrm{g} / \mathrm{mL}$ for PSNP and $0.01,0.1$, and $1 \mu \mathrm{g} / \mathrm{mL}$ for the PBmix. The PSNP + PBmix cocktails contained the same concentrations of the two components as described above.

For the viability assay we used two controls. The positive control consisted of cells treated with $1 \%$ Triton X-100 and the negative control of cells treated with sterile PBS (PSNP solvent) and ethanol (PBmix solvent) in the same volumes that were used for PSNP or PBmix treatment.

For the proliferation assay, cells treated with $10 \%$ DMSO served as positive control for inhibited cell proliferation (without complete cell disintegration as with Triton X-100) and negative controls were the same as in the viability assay.

Plates were then incubated at $37^{\circ} \mathrm{C}$ and $5 \% \mathrm{CO}_{2}$ for $24 \mathrm{~h}$ for the viability (MTS) assay and for $120 \mathrm{~h}$ for the proliferation (Ki67) assay.

\section{Cell viability assay}

Metabolic activity in treated cells was determined with the CellTiter 96® AQueous One Solution Cell Proliferation Assay, which is based on the reduction of the yellow tetrazolium salt MTS ([3-(4,5-dimethylthiazol-2-yl)-5-(3carboxymethoxyphenyl)-2-(4-sulfophenyl)-2Htetrazolium) to formazan. The amount of produced formazan was measured by light absorbance at $490 \mathrm{~nm}$ on a spectrophotometer, and is proportional to the number of viable cells. MDA-MB 231 and MCF-7 cells were plated and treated as described above. At the end of $24 \mathrm{~h}$ treatment, the medium from each well was removed by aspiration and cells were washed three times with $200 \mu \mathrm{L}$ of PBS per well. Fresh culture medium was then added, followed by MTS reagent solution. After $3 \mathrm{~h}$ of incubation at $37^{\circ} \mathrm{C}$ and $5 \%$ $\mathrm{CO}_{2}$, absorbance was read at $490 \mathrm{~nm}$ on a Victor 3 Multilabel Plate Reader (PerkinElmer Inc., Waltham, MA, 
USA) and normalised to control cell absorbance values (A490 sample $/ A 490_{\text {control }} * 100 \%$ ) to obtain the percentages of cell viability for each treatment group, expressed as means and standard deviations (mean $\pm \mathrm{SD}$ ).

\section{Proliferation assay}

Proliferation of MDA-MB 231 and MCF-7 cells was quantified with a Muse ${ }^{\circledR}$ Ki67 Proliferation Kit. The percentage of proliferating cells was determined by fluorescent labelling of the Ki-67 protein, a nuclear antigen used as a marker of proliferation. Cells were plated and treated with PSNP or PBmix as described above, after which they were incubated at $37^{\circ} \mathrm{C}$ and $5 \% \mathrm{CO}_{2}$ for 5 days. After incubation, culture medium was removed from the wells, cells washed twice with sterile PBS, and $0.25 \%$ trypsinEDTA solution added to detach the cells. After $5 \mathrm{~min}$ of incubation at $37{ }^{\circ} \mathrm{C}$ and $5 \% \mathrm{CO}_{2}$, fresh culture medium was added to inactivate trypsin, and cells collected in $2 \mathrm{~mL}$ Eppendorf tubes. Cells were then labelled using the Ki67 Proliferation Kit according to manufacturer's instructions and were acquired on Muse Cell Analyzer (Luminex Corporation, Madison, Wisconsin, USA). Unstained control cells were used for gating to determine the percentage of proliferating, Ki67-positive cells in the samples. Means and standard deviations were calculated from percentages of viability. Percentages of proliferating (Ki67 positive) cells were used to calculate means \pm SD for each treatment.

\section{Statistical analysis}

For statistical analysis we used the GraphPad Prism 6.0 software (San Diego, CA, USA) to run one-way ANOVA followed by Dunnett's multiple comparison test to compare mean values of individual treatments with control means. Significance threshold was set at $P<0.05$.

\section{RESULTS AND DISCUSSION}

Cell viability results (Figure 1) showed a dosedependent drop in the cell viability of MDA-MB 231 cells treated separately with PBmix or PSNPs or their combination. Although this drop crossed the threshold of statistical significance in all combined treatments, only the treatment with $1 \mu \mathrm{g} / \mathrm{mL}$ PBmix combined with 10 or $100 \mu \mathrm{g} / \mathrm{mL}$ PSNPs resulted in viability loss above $80 \%$, which is conventionally considered the biologically significant threshold. Therefore, only the PBmix + PSNP cocktail was able to significantly decrease cell viability of MDA-MB 231 cells. However, this was not a clear sign of their cytotoxicity, as we did not measure the number of dead cells or establish the mechanism of cell death, but focused on the number of metabolically active cells.

In contrast, MCF-7 cells showed a consistent increase in cell viability when treated separately with PSNP or PBmix, as well as with the combination of $0.01 \mu \mathrm{g} / \mathrm{mL}$ PBs $+100 \mu \mathrm{g} / \mathrm{mL}$ PSNP. Higher concentrations of PBmix or PSNP in the combination did not induce any significant changes in cell viability. These results point to the possibility of stimulated cell proliferation, which was further explored with the Ki-67 assay.

Cell proliferation findings underscore the differences between MCF-7 and MDA-MB 231 cells in response to combined PBmix + PSNP treatment (Figure 2). The percentages of proliferating (Ki67-positive) MDA-MB 231 cells dropped in all treatments (PBmix, PSNP, and PBmix + PSNP cocktails) compared to control cells, but the drop was significant only for the PBmix concentration of $1 \mu \mathrm{g} / \mathrm{mL}$. As in cell viability, MCF-7 cells again showed opposite findings, that is, a dose-dependent increase in cell proliferation after treatment with PBmix, but this increase was not significant. Treatment with PSNPs alone did not
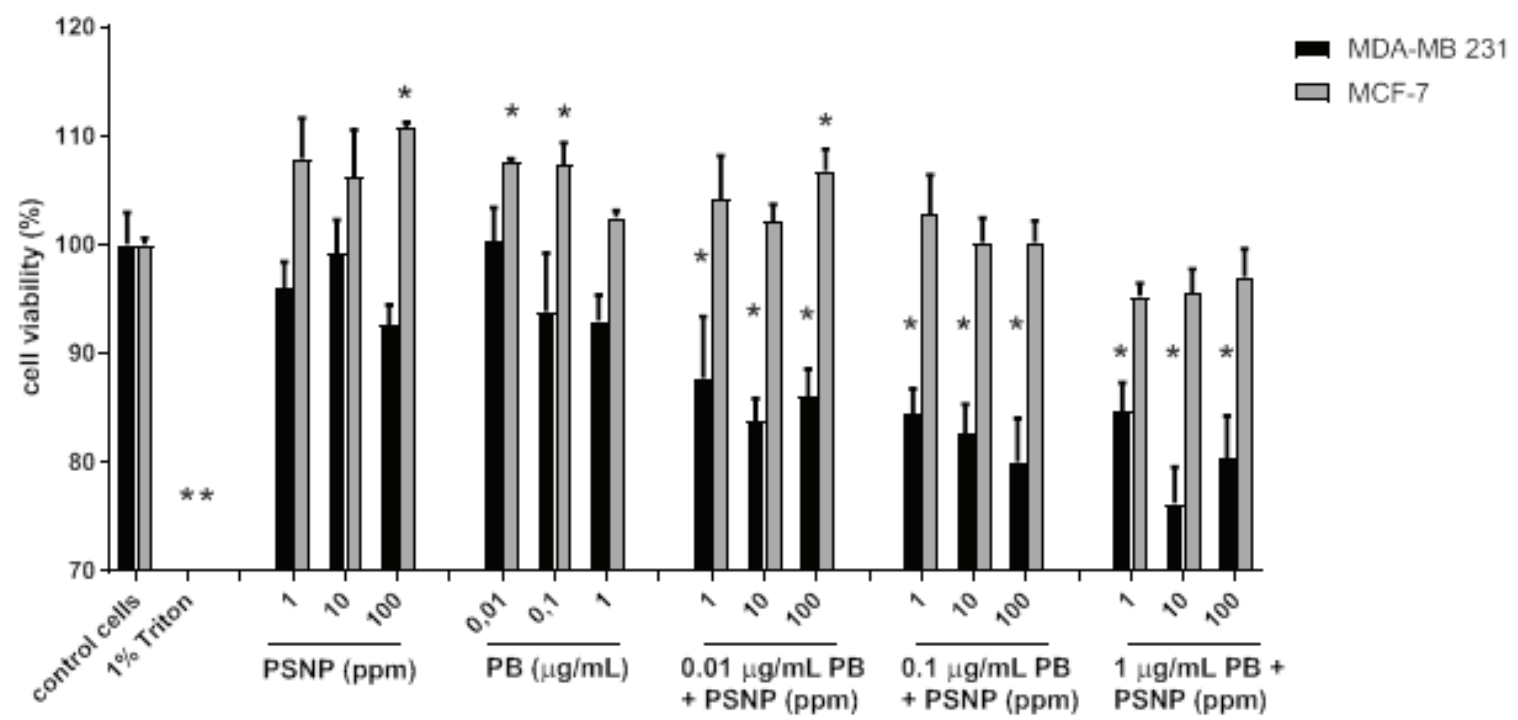

Figure 1 Effects of parabens (PB) and/or polystyrene nanoparticles (PSNP) on breast cancer cell viability. * significantly different $(\mathrm{P}<0.05)$ from negative control 


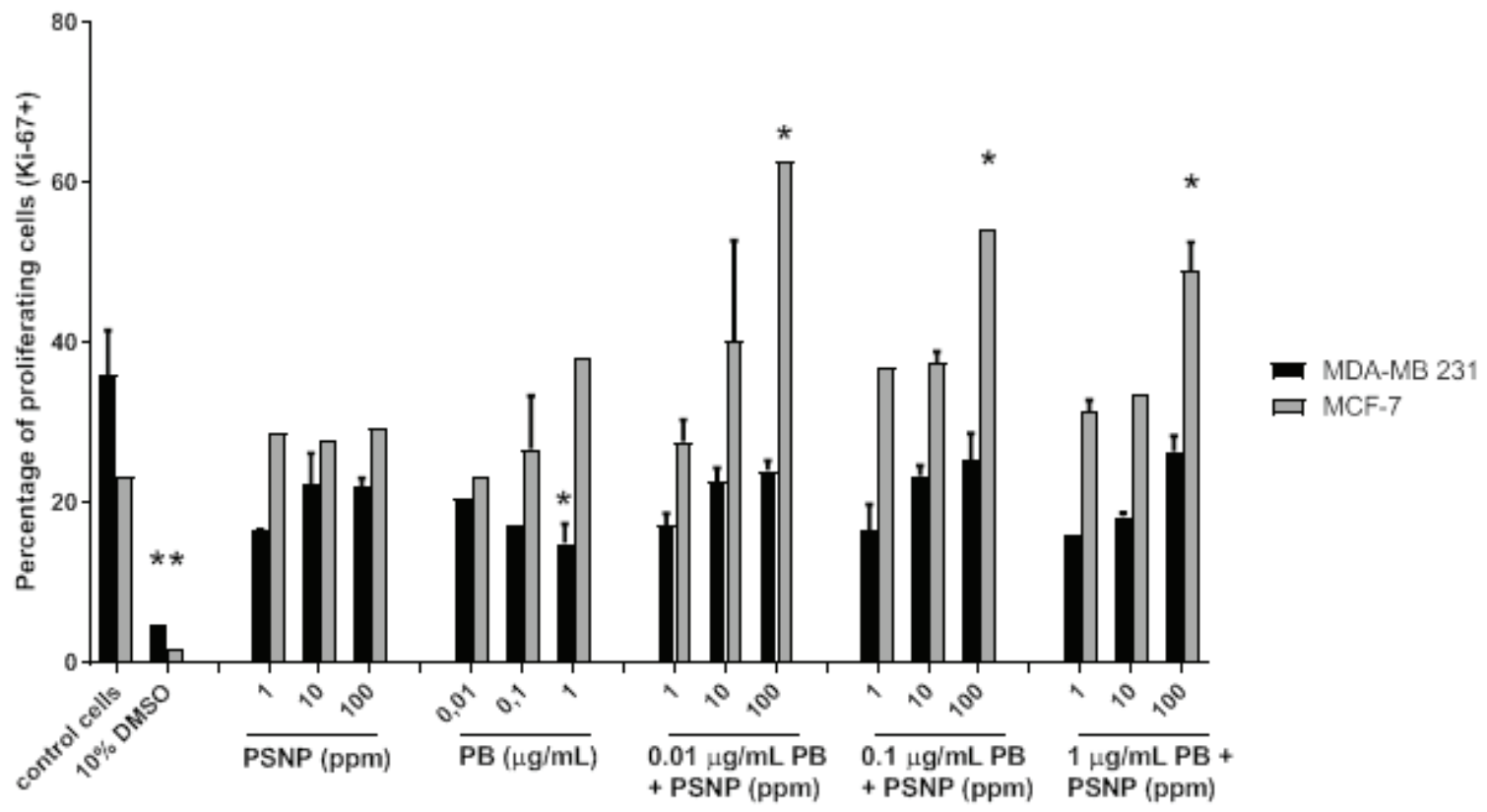

Figure 2 Effects of parabens (PB) and/or polystyrene nanoparticles (PSNP) on breast cancer cell proliferation. * significantly different $(\mathrm{P}<0.05)$ from negative control

increase cell proliferation compared to controls. Considering the differences in cell surface receptors between the two cell lines and the well-known interactions between parabens and oestrogen receptors, these results were expected.

The most interesting findings were obtained with the PBmix + PSNP combinations. The percentages of proliferating (Ki67-positive) cells increased significantly and more than doubled at the highest PSNP concentrations, irrespective of the PBmix concentrations (Figure 2). These observations indicated that the proliferation activity of PBmix in oestrogen-sensitive breast cancer cells was synergistically driven by the presence of PSNP. A mechanism that stands behind it could be related to the translocation and adsorption properties of PSNP, acting like a Trojan horse to expose cells to parabens more efficiently. Exposure to a chemical cocktail such as this is therefore expected to promote proliferation of oestrogen-sensitive cells and greatly contribute to the development of breast cancer.

\section{CONCLUSION}

This preliminary study warns against the risks of synergistic effects of chemical cocktails containing plastics nanoparticles and EDCs on proliferation of human breast cancer cells, which calls for a clearly defined action plan for risk management of EDCs and plastic waste at the global level. Risk assessment of exposure to chemical mixtures reflects real-life scenarios, but experimental evaluation of all possible combinations is almost impossible. Our knowledge may therefore benefit from simulating these combinations with advanced mathematical and statistical models based on results obtained for simpler mixtures. To achieve this objective, more research is needed to unveil the mechanisms behind mixture effects and to carefully consider all types of chemicals that should be included in a given risk assessment of EDCs.

\section{Conflicts of interest}

None to declare.

\section{Acknowledgements}

We wish to thank the Croatian Science Foundation for financial support of this work (grant No. HRZZIP-2016-06-2436). The authors are grateful to Dr Adela Krivohlavek from the Andrija Štampar Teaching Institute of Public Health for help in purchasing parabens.

\section{REFERENCES}

1. European Chemicals Agency (ECHA). Consolidated version of the REACH Regulation [displayed 23 November 2019]. Available at https://echa.europa.eu/regulations/reach/ legislation

2. European Environmental Bureau (EEB). A third of chemicals break EU safety laws [displayed 12 October 2018]. Available at https://eeb.org/a-third-of-chemicals-break-eu-safety-laws/

3. World Health Organization (WHO). State of the science of endocrine disrupting chemicals - 2012. An assessment of the state of the science of endocrine disruptors prepared by a group of experts for the United Nations Environment Programme [displayed 23 November 2019]. Available at https://www.who.int/iris/bitstream/10665/78101/1/ 9789241505031_eng.pdf?ua=1 
4. European Commission. Communication from the commission to the european parliament, the council, the european economic and social committee and the committee of the regions. Towards a comprehensive European Union framework on endocrine disruptors [displayed 23 November 2019]. Available at https://eur-lex.europa.eu/legal-content/ EN/ALL/?uri=CELEX\%3A52015DC0614

5. Health and Environment Alliance (HEAL). Health Costs in the European Union. How Much is Related to the EDCs? [displayed 23 November 2019]. Available at http://www. env-health.org/IMG/pdf/18062014 final_health_costs_in the_european_union_how_much_is_realted_to_edcs.pdf

6. European Environment Agency (EEA). Late lessons from Early Warnings. [displayed 23 November 2019]. Available at https://www.eea.europa.eu/publications/late-lessons-2

7. Routledge EJ, Parker J, Odum J, Ashby J, Sumpter JP. Some alkyl hydroxyl- benzoate preservatives (parabens) are estrogenic. Toxicol Appl Pharmacol 1998;153:12-9. doi 10.1006/taap.1998.8544

8. Wróbel A, Gregoraszczuk EŁ. Effects of single and repeated in vitro exposure of three forms of parabens, methyl-, butyland propylparabens on the proliferation and estradiol secretion in MCF-7 and MCF-10A cells. Pharmacol Rep 2013;65:484-93. doi: 10.1016/s1734-1140(13)71024-7

9. Pop A, Drugan T, Gutleb AC, Lupu D, Cherfan J, Loghin F, Kiss B. Estrogenic and anti-estrogenic activity of butylparaben, butylated hydroxyanisole, butylated hydroxytoluene and propyl gallate and their binary mixtures on two estrogen responsive cell lines (T47D-Kbluc, MCF-7). J Appl Toxicol 2018;38:1-14. doi: 10.1002/jat.3601

10. Charles AK, Darbre PD. Combinations of parabens at concentrations measured in human breast tissue can increase proliferation of MCF-7 human breast cancer cells. J Appl Toxicol 2013;33:390-8. doi: 10.1002/jat.2850

11. Khanna S, Dash PR, Darbre PD. Exposure to parabens at the concnetration of maximal proliferative response increases migratory and invasive activity of human breast cancer cells in vitro. J Appl Toxicol 2014;34:1051-9. doi: 10.1002/ jat.3003

12. Darbre PD, Aljarrah A, Miller WR,Coldham NG, Sauer MJ, Pope GS. Concentrations of parabens in human breast tumors. J Appl Toxicol 2004;24:5-13. doi: 10.1002/jat.958

13. Kjærstad MB, Taxvig C, Andersen HR, Nellemann C. Mixture of endocrine disrupting compunds in vitro. Int $\mathrm{J}$ Androl 2010;33:425-33. doi: 10.1111/j.1365-2605. 2009.01034.x

14. Yang CZ, Yaniger SI, Jordan VC, Klein DJ, Bittner GD. Most plastic products release estrogenic chemicals: a potential health problem that can be solved. Environ Health Perspect 2011;19:989-96. doi: 10.1289/ehp.1003220

15. Lehner R, Weder C, Petri-Fink A, Rothen-Rutishauser B. Emergence of nanoplastic in the environment and possible impact on human health. Environ Sci Technol 2019;53:174865. doi: 10.1021/acs.est.8b05512

16. Eriksen M, Lebreton LCM, Carson HS, Thiel M, Moore CJ, Borerro JC, Galgani F, Ryan PG, Reisser J. Plastic pollution in the world's oceans: more than 5 trillion plastic pieces weighing over 250,000 tons afloat at sea. Plos One 2014;9(12):e111913. doi: 10.1371/journal.pone.0111913

17. Galloway TS. Micro- and nano-plastics and human health. In: Bergmann M, Gutow L, Klages M, editors. Marine anthropogenic litter. Cham: Springer; 2015. p. 343-66.

\section{Sinergistički učinak parabena i nanoplastike na proliferaciju humanih stanica raka dojke}

Većina proizvoda za osobnu njegu na tržištu sadrži kemikalije koje remete rad endokrinoga sustava kao što su parabeni. Primjena takvih proizvoda povećava izloženost opće populacije takvim kemikalijama. Parabeni, dobro poznati aditivi koji se koriste kao konzervansi, otkriveni su u mliječnim žlijezdama i tkivima raka dojke. Osim takvih kemikalija, izloženost plastičnim mikro- i nanočesticama koje nastaju tijekom proizvodnje, uporabe i odlaganja plastičnog otpada velik su zdravstveni i okolišni problem koji treba hitno rješavati. Za pouzdanu procjenu rizika za ljudsko zdravlje, nužno je objasniti ne samo učinke pojedinačnih kemijskih spojeva nego i njihovih mješavina. Istraživanje izloženosti kemijskim koktelima može pružiti podatke o mogućem sinergističkom ili aditivnom učinku kemikalija u takvim koktelima. Cilj ovoga istraživanja bio je procijeniti učinak plastičnih nanočestica, parabena i njihovih koktela na vijabilnost i proliferaciju dviju različitih stanica karcinoma dojke: stanične linije MDA-MB 231 kojoj nedostaju estrogeni receptori i MCF-7 stanica koje izražavaju te receptore. Dobiveni rezultati pokazali su da ni parabeni ni plastične nanočestice, primijenjeni posebno, $\mathrm{u}$ ispitivanim koncentracijskim rasponima nisu značajnije promijenili vijabilnost i proliferacijsku aktivnost $\mathrm{u}$ stanicama karcinoma dojke. Međutim, parabeni su pojačali proliferacijsku aktivnost stanica osjetljivih na estrogene koja je sinergistički potaknuta prisutnošću plastičnih nanočestica. Mehanizam takva djelovanja može biti povezan s translokacijskim i adsorpcijskim svojstvima nanočestica, koje su poslužile kao vektor za učinkovitije izlaganje stanica parabenima. Protumorska aktivnost na karcinomu dojke može se očekivati kao konačni ishod izloženosti takvom kemijskom koktelu. Ovi preliminarni podatci dragocjeni su dodatak postojećim ranim upozorenjima na novi problem s povećanjem izloženosti ljudi plastičnom otpadu i kemijskim kemikalijama. 